\title{
The effects of varying types of protein consumption on measures of strength in collegiate football players
}

\author{
Caleb Woodall ${ }^{1 *}$, Jordan Hattaway ${ }^{1}$, Chad Kerksick ${ }^{3}$, Mike Sedlak4, Lem Taylor ${ }^{1,2}$, Colin Wilborn ${ }^{1,2}$ \\ From International Society of Sports Nutrition; 7th Annual ISSN Conference and Expo \\ Clearwater Beach, FL, USA. 24-26 June 2010
}

\section{Background}

To investigate the potential effects of three types of protein ingestion in conjunction with a controlled resistance training program utilizing Division III college male football players.

\section{Methods}

74 NCAA Division III male football players were matched according to weight and randomly assigned in a double blind manner into 4 groups to consume either 40 grams of a whey and casein protein blend (WC) $(94.5 \pm 21.8 \mathrm{~kg}, 19.6 \pm 2.5 \mathrm{yrs}, 180 \pm 6 \mathrm{~cm}, 18.6 \pm 8.9$ $\%)$, whey protein (WP) $(90.4 \pm 15.9 \mathrm{~kg}, 19.6 \pm 1.3 \mathrm{yrs}$, $177.8 \pm 6.6 \mathrm{~cm}, 16.5 \pm 6.7 \%)$, casein protein $(\mathrm{CC})$ $(107.2 \pm 14 \mathrm{~kg}, 19.7 \pm 1.1 \mathrm{yrs}, 182 \pm 6 \mathrm{~cm}, 21.6 \pm 7 \%)$, or a glucose control (GC) $(96.4 \pm 18.1 \mathrm{~kg}, 19.7 \pm 1.4$ yrs, $180 \pm 6 \mathrm{~cm}, 16 \pm 5.1 \%)$ post-exercise for eight weeks. In addition to the supplementation, subjects participated in a supervised 5-day per week linearly periodized training program. At 0 and 8 -weeks, subjects underwent DEXA body composition analysis, 1RM strength, 40 yard dash, vertical jump, and 5-10-5 testing sessions. Data were analyzed using a $4 \times 2$ mixed factorial ANOVA. Follow-up one way ANOVA were used as a post-hoc measure with delta scores. All data is presented as mean \pm SD changes from baseline after 60-days.

\section{Results}

No significant group $x$ time interaction effects were observed among groups in changes in any performance variable $(p>0.05)$. However, significant time effect

${ }^{1}$ Human Performance Laboratory, University of Mary Hardin-Baylor, Belton,

TX 76513, USA

Full list of author information is available at the end of the article
( $\mathrm{p}<0.05$ ) were observed in squat $1 \mathrm{RM}$ (WC: $18 \pm 13.7$ kg, WP: $31.6 \pm 20.5 \mathrm{~kg}$, CC: $23.6 \pm 17.3 \mathrm{~kg}, \mathrm{GC}: 25.7 \pm$ $17.9 \mathrm{~kg}$ ), bench press $1 \mathrm{RM}$ (WC: $10.3 \pm 7.2 \mathrm{~kg}$, WP: 16 $\pm 8.9 \mathrm{~kg}$, CC: $9.9 \pm 11.5 \mathrm{~kg}$, GC: $11.6 \pm 7.8 \mathrm{~kg}$ ), power clean 1RM (WC: $8.1 \pm 5.6 \mathrm{~kg}$, WP: $6.9 \pm 6.5 \mathrm{~kg}$, CC: 3.4 $\pm 5.4 \mathrm{~kg}$, GC: $5.7 \pm 6.3 \mathrm{~kg}$ ), 40 yard dash (WP: $-0.05 \pm$ $0.09 \mathrm{~kg}$, CC: $-0.06 \pm 0.11 \mathrm{~kg}$ ), vertical jump (WC: $2.2 \pm$ $2.2 \mathrm{~kg}$, WP: $1.3 \pm 1.7 \mathrm{~kg}$, GC: $1.5 \pm 1.5 \mathrm{~kg}$ ), and $5-10-5$ (CC: $-0.055 \pm 1.0 \mathrm{~kg}, \mathrm{GC}:-0.09 \pm 0.08 \mathrm{~kg}$ ) in all groups. In regards to body composition there were also significant $(p<0.05)$ time effects for fat mass, fat free mass, lean mass, and percent body fat. A significant group $\mathrm{x}$ time interaction was observed for fat mass where CC lost more fat than WP and GC (CC: $-1.90 \pm 1.7$, WP: $-0.64 \pm 1.3$, GC: $-0.44 \pm 1.3$ ).

\section{Conclusion}

It has been concluded that eight weeks of supplementation with protein or carbohydrate, either whey or casein, might have a significant impact on muscular strength adaptations and body composition that occur with controlled resistance training. The resistance training protocol utilized resulted in increases in muscular strength and lean mass, with a decrease in body fat mass and percentage, indicating that the stimulus was sufficient enough to produce the desired adaptations in resistance trained, collegiate athletes. However there were no significant interactions between groups, suggesting that all forms of supplementation were similar in their ability to facilitate performance adaptations. Despite the lack of performance changes, casein protein appeared to facilitate the greatest fat loss when compared to whey protein or carbohydrate. 


\section{Acknowledgment}

Clinically Proven Consultants \& Associates (Toronto, ON) supplied research supplements.

\section{Author details}

${ }^{1}$ Human Performance Laboratory, University of Mary Hardin-Baylor, Belton,

TX 76513, USA . ${ }^{2}$ Exercise Biochemistry Laboratory, University of Mary Hardin-

Baylor, Belton, TX 76513, USA. ${ }^{3}$ Applied Biochemistry and Molecular

Physiology Laboratory, University of Oklahoma, Norman, OK 73019, USA .

${ }^{4}$ Clinically Proven Consultants \& Associates, Toronto, ON, Canada.

Published: 15 September 2010

doi:10.1186/1550-2783-7-S1-P13

Cite this article as: Woodall et al:: The effects of varying types of

protein consumption on measures of strength in collegiate football

players. Journal of the International Society of Sports Nutrition 2010 7(Suppl 1):P13

Submit your next manuscript to BioMed Central and take full advantage of:

- Convenient online submission

- Thorough peer review

- No space constraints or color figure charges

- Immediate publication on acceptance

- Inclusion in PubMed, CAS, Scopus and Google Scholar

- Research which is freely available for redistribution

Submit your manuscript at www.biomedcentral.com/submit 